
\title{
R Reserarch Soute \\ Stable red blood cell concentrations seen in astronauts on long space missions
}

Hawley Kunz

Heather Quiriarte

Richard J. Simpson

Robert Ploutz-Snyder

Kathleen McMonigal

Clarence Sams

Brian Crucian

\section{Video Abstract}

Keywords: red blood cell, space flight, NASA, astronaut, hematology, BMC Hematology, anemia,

Posted Date: November 21st, 2020

DOI: https://doi.org/10.21203/rs.3.rs-113090/v1

License: (c) (i) This work is licensed under a Creative Commons Attribution 4.0 International License.

Read Full License 


\section{Abstract}

Radiation, weightlessness, and altered nutrition are just a few of the harsh conditions astronauts face while in space. Though blood parameters_do_ change during space flight, a new study published in the journal, _BMC Hematology____suggests crews on long missions may not experience persistent anemia, as once thought. Environmental conditions in space are undoubtedly different from those on Earth, and can, therefore, impact a number of the body's systems including vision, immunity, and the musculoskeletal system. It is well understood that, upon entering microgravity, fluids rapidly shift toward the head -- evident by the so-called 'puffy-face syndrome' seen in many astronauts. It has been assumed that during long-duration space missions, this is accompanied by a state of anemia - a condition that occurs when the body fails to produce a sufficient levels of oxygen-carrying red blood cells and can result in weakness and fatigue. While red blood cell counts, hemoglobin, and plasma volume have been studied in short spaceflights, most studies have analyzed blood collected post-flight and little is known about how these parameters change during long missions. As part of an investigation into the effects of longduration spaceflight on the immune system, NASA scientists collected blood from astronauts onboard the International Space Station. Samples were taken before, during, and, after flight and sent back to Earth where they were analyzed for red blood cell and platelet levels. Surprisingly, the researchers found a significant increase in red blood cell percentage - relative to total blood volume - while the astronauts were in flight, even when considering the effects of delayed sample processing for the samples collected on the Space Station. This hematocrit spike suggests the body may be able to adjust to the absence of gravity as flight duration increases. While there are many difficulties astronauts must manage while on long space missions, persistent anemia doesn't appear to be one of them. Though further work is needed, this study provides important insights into potential medical risks crews experience during orbital spaceflight, and will inform upcoming deep space exploration missions. 